\title{
Balsamic Vinegar Improves High Fat-Induced Beta Cell Dysfunction via Beta Cell ABCA1 (Diabetes Metab J 2012;36:275-9)
}

\author{
Hannah Seok, Bong Soo Cha \\ Division of Endocrinology and Metabolism, Department of Internal Medicine, Yonsei University College of Medicine, Seoul, Korea
}

We sincerely appreciate the interest and comments regarding our study, "Balsamic Vinegar Improves High Fat-Induced Beta Cell Dysfunction via Beta Cell ABCA1," which was published in Diabetes \& Metabolism Journal 2012;36:275-9. Our responses to Dr. Cho's comments follow.

The main pathogenesis of type 2 diabetes is well known as it entails decreased pancreatic $\beta$-cell dysfunction and increased insulin resistance [1]. $\beta$-cell dysfunction was closely correlated with glucotoxicity and lipotoxicity [2-4]. Our study showed that balsamic vinegar treatment increased insulin secretion in pancreatic $\beta$-cell, and this was associated with increased ABCA1 expression and increased cholesterol excretion in $\beta$-cell. Based on these results, we suggested that balsamic vinegar could improve $\beta$-cell dysfunction by decreasing lipotoxicity.

However, our study failed to demonstrate a change in pancreatic $\beta$-cell mass after balsamic vinegar treatment. We also did not measure insulin levels nor did we quantify cholesterol levels in $\beta$-cell, as Dr. Cho pointed out. These are potential limitations of our study.

Our study showed the effect of balsamic vinegar on reducing lipotoxicity, and its potential for the treatment of diabetes. Further investigation is warranted to demonstrate the effect of balsamic vinegar on $\beta$-cell dysfunction more clearly, and to clarify the mechanisms that account for the relationship be- tween balsamic vinegar, lipotoxicity and $\beta$-cell dysfunction.

Thank you for taking interest in this study and for your thoughtful comments.

\section{CONFLICTS OF INTEREST}

No potential conflict of interest relevant to this article was reported.

\section{REFERENCES}

1. Weyer C, Bogardus C, Mott DM, Pratley RE. The natural history of insulin secretory dysfunction and insulin resistance in the pathogenesis of type 2 diabetes mellitus. J Clin Invest 1999; 104:787-94.

2. Unger RH. Lipotoxicity in the pathogenesis of obesity-dependent NIDDM. Genetic and clinical implications. Diabetes 1995; 44:863-70.

3. Sivitz WI. Lipotoxicity and glucotoxicity in type 2 diabetes. Effects on development and progression. Postgrad Med 2001;109: 55-9, 63-4.

4. Poitout V, Robertson RP. Minireview: secondary beta-cell failure in type 2 diabetes--a convergence of glucotoxicity and lipotoxicity. Endocrinology 2002;143:339-42.
Corresponding author: Bong Soo Cha

Department of Internal Medicine, Yonsei University College of Medicine,

50 Yonsei-ro, Seodaemun-gu, Seoul 120-752, Korea

E-mail: bscha@yuhs.ac
This is an Open Access article distributed under the terms of the Creative Commons Attribution Non-Commercial License (http://creativecommons.org/licenses/by-nc/3.0/) which permits unrestricted non-commercial use, distribution, and reproduction in any medium, provided the original work is properly cited. 